\title{
Prevalence and Predictors of Malnutrition among patients on Maintenance Haemodialysis in a Tertiary Care Centre, Sri Lanka
}

\author{
Ratnapala DUS, Rajmohan B, Mulkirigala A, Perera CSN \\ Renal Department, Aberdeen Royal Infirmary, Foresterhill, Aberdeen \\ AB25 2ZN, UK
}

\section{Introduction}

Chronic kidney disease (CKD) is a mammoth public health issue, the tide of which continues to rise continuously [1]. Approximately 2.5 million receive renal replacement therapy in the world and it is projected to double to 5.4 million by 2030 [1].

Maintenance haemodialysis (MHD) is the most widely utilised renal replacement therapy in patients with advanced kidney disease [1].

Although, Haemodialysis improves survival in end stage renal disease, the therapy and disease is associated with multiple acute and chronic complications. Malnutrition being one such complication shows a significant prevalence in haemodialysis population [1].

The aetiology of malnutrition is multifactorial. It includes poor food intake, hormonal and gastrointestinal disorders, and restricted diets, drugs that alter nutrient absorption, subtherapeutic dialysis, and associated comorbidities.

Malnutrition is considered an indicator of poor prognosis in CKD $[1,2]$. The nutritional status of HD population is inversely associated with augmented risk of hospitalization and mortality; thus making it a crucial determinant of the outcome of these patients. Therefore, assessing the nutritional status is critical both to prevent malnutrition and for appropriate intervention in malnourished patients [1]. Therefore, a successful haemodialysis outcome is dependent on adequate nutrition.

Conventional nutritional assessment tools include anthropometry measurements, dietary energy and protein intakes and biochemical measurements, which are impractical in the routine use. Subjective Global Assessment (SGA) is a tool used by health care providers to assess nutritional status and help to predict nutrition related clinical outcomes. SGA was evaluated in different studies as an adequate tool for the assessment of nutritional status in dialysis patients $(8,9)[1,2]$.
${ }^{*}$ Corresponding author

Ratnapala DUS, Renal Department, Aberdeen Royal Infirmary, Foresterhill, Aberdeen AB25 2ZN, UK

Submitted: 27 Apr 2020; Accepted: 07 May 2020; Published: 03 Jul 2020

Kalantar-Zadeh et al developed alternative version of SGA, initially called the modified quantitative SGA and subsequently known as the Dialysis Malnutrition Score (DMS).

The DMS was reported to be more reliable than the conventional SGA in number of studies was described to correlate with age, dialysis duration, mid-arm muscle circumference (MAMC), BMI, serum albumin concentration, and total iron-binding capacity (TIBC) which were markers of malnutrition and inflammation $[1,2]$.

Though, malnutrition had been proven to be common and important predictor of adverse outcome throughout the world, there is no published literature assessing nutritional status among dialysis population in Sri Lanka. Therefore, this study was aimed to determine the prevalence, predisposing factors of malnutrition in MHD patients at a tertiary care haemodialysis centre in Sri Lanka utilising dialysis malnutrition score and conventional nutritional tools.

\section{Method}

This was a descriptive cross sectional survey carried out in the haemodialysis unit, District General Hospital, Trincomalee. All the patients underwent haemodialysis for end stage diseases from 1st June 2018 to 30th September 2018 were included.

Inclusion criteria were patients with end stage renal failure who were dialysed at district general hospital, Trincomalee, receiving haemodialysis for at least one month and aged more than 18 years at the date of survey.

We excluded patients who did not give consent, were unable to answer the questionnaire (difficulty in understanding questions, visual or hearing impairment), and had a previous kidney transplant or patients needing dialysis due to acute kidney injury.

Patients were interviewed during the dialysis session using an interviewer administered questionnaire to gather demographic, socioeconomic, and clinical data. Variables such as gender, age, ethnicity, family income and data on dialysis provision were gathered. 
Nutritional status was evaluated by a trained dialysis nurse using a dialysis malnutrition score at the time of the interview. The patient also underwent anthropometric measurements and biochemical investigations.

\section{Anthropometric Measurements}

The body weight and skin-fold measurements were performed after termination of the dialysis session. Triceps skin-fold thickness (TSF) was measured in the midpoint between the acromion process and the olecranon process in the upper arm using a caliper. Mid-arm circumference (MAC) was measured using a tape measure at the same level. The measurements mentioned above were performed two times on the non-access arm of each dialysis patient and the average of two results was taken as the final value. Mid-arm muscle circumference (MAMC) was derived according to the following formula: MAMC $=\mathrm{MAC}-(0.31415 \mathrm{x} \mathrm{TSF})$. Body mass index (BMI) was calculated as the ratio between post dialysis body weight in kilogram and the square of height in meter.

\section{Modified Subjective Global Assessment-Dialysis Malnutrition Score (DMS)}

The modified SGA has been indicated as a reliable and valid tool for the nutritional assessment for patients who are undergoing haemodialysis. The modified SGA includes two major categories: the history and physical examination. The history portion is comprised of five sections: weight/weight change; dietary intake; gastrointestinal symptoms; functional capacity; and disease state/ co-morbidities as related to nutritional status. The second major category is the physical examination including an evaluation of the patient for fat and muscle wasting and presence of oedema. Each component has a score between one (normal) to five (very severe). Thus MS has a total score between 7 and 35. After completion DMS, patients were placed in one of three groups. Patients having DMS score between7-10 were considered as wellnourished patients. DMS score between11-22 were considered as having mild to moderate malnutrition. Likewise score between 23 and 35 were considered as severely malnourished [1].

\section{Biochemical Investigations}

The patients were also evaluated for biochemistry including serum albumin, and serum cholesterol after 12 hours fasting and prior to dialysis session.

\section{Data Analysis}

Data was analysed using the SPSS version 17. Data was presented as mean $\pm \mathrm{SD}$ (parametric data) and median \pm interquartile range (nonparametric data) and percentage patients (\%). Pearson correlation coefficient ' $r$ ' (parametric data) and the Spearman rank correlation coefficient (non-parametric data) was used to assess the strength of associations between various nutritional variables.

\section{Ethical considerations}

Ethical approval for the study was obtained from Ethical review committee, National Hospital of Sri Lanka. Informed written consent was obtained from each participant.

\begin{tabular}{|c|c|}
\hline Results & \\
\hline Characteristic & Value \\
\hline $\begin{array}{l}\text { Age (years) mean+-SD } \\
\text { Median } \\
\text { IQR }\end{array}$ & $\begin{array}{l}51.12+-13.4 .2 \\
54 \\
43.0-61.0\end{array}$ \\
\hline $\begin{array}{l}\text { Gender }(\mathrm{n} / \%) \\
\text { Male } \\
\text { Female }\end{array}$ & $\begin{array}{l}41(63.1 \%) \\
24(36.9 \%)\end{array}$ \\
\hline $\begin{array}{l}\text { Ethnicity }(\mathrm{n} / \%) \\
\text { Tamil } \\
\text { Muslim } \\
\text { Sinhala } \\
\end{array}$ & $\begin{array}{l}25(38.46) \\
26(40.0 \%) \\
14(21.5 \%) \\
\end{array}$ \\
\hline $\begin{array}{l}\text { Monthly Family income (SLR) } \\
\text { US\$(mean+-SD) }\end{array}$ & $\begin{array}{l}17253.85+-16171.958 \\
86.27+-80.25\end{array}$ \\
\hline $\begin{array}{l}\text { Primary kidney disease }(\mathrm{n} / \%) \\
\text { HTN } \\
\text { DM } \\
\text { APCKD } \\
\text { CGN } \\
\text { CKDU }\end{array}$ & $\begin{array}{l}36(55.38 \%) \\
19(29.23 \%) \\
2(3.07 \%) \\
3(4.61 \%) \\
5(7.69 \%)\end{array}$ \\
\hline $\begin{array}{l}\text { Haemodialysis duration (months) } \\
\text { mean+-SD }\end{array}$ & $13.68+-11.62$ \\
\hline $\begin{array}{l}\text { Number of haemodialysis per week (n/\%) } \\
1 \\
2 \\
3\end{array}$ & $\begin{array}{l}12(18.46 \%) \\
43(66.15 \%) \\
10(15.38 \%)\end{array}$ \\
\hline $\begin{array}{l}\text { Vascular access }(\mathrm{n} / \%) \\
\text { Temporary HD Catheter } \\
\text { Permanent HD Catheter } \\
\text { AVF }\end{array}$ & $\begin{array}{l}15(23.07 \%) \\
12(18.46 \%) \\
38(58.46 \%)\end{array}$ \\
\hline
\end{tabular}

Table 1: Sociodemographic and haemodialysis parameters $\mathrm{SD}=$ Standard Deviation, $\mathrm{IQR}=$ Interquartile range, $\%=$ percentage, $\mathrm{SLR}=$ Sri Lankan Rupees, HTN= Hypertension, $\mathrm{DM}=$ Diabetes mellitus, $\mathrm{APCKD}=$ Adult Polycystic Kidney Disease, $\mathrm{CGN}=$ Chronic Glomerulonephritis, $\mathrm{CKDU}=$ Chronic Kidney Disease of Unknown Origin, $\mathrm{HD}=$ Haemodialysis, $\mathrm{AVF}=$ Arteriovenous Fistula

\begin{tabular}{|l|l|}
\hline DMS Category & $\mathbf{n} / \mathbf{\%}$ \\
\hline Well nourished & $14(21.5 \%)$ \\
\hline Mild to Moderate Malnutrition & $51(78.5 \%)$ \\
\hline Severe Nutrition & 0 \\
\hline
\end{tabular}

Table 2: Categorisation of Malnutrition by DMS

DMS $=$ Dialysis Malnutrition Score, $n=$ number, $\%=$ Percentage

\begin{tabular}{|l|l|}
\hline Nutritional assessment tool & Mean+-SD \\
\hline DMS & $13.91+-4.193$ \\
\hline BMI $\left(\mathrm{kg} / \mathrm{m}^{2}\right)$ & $22.39+-5.127$ \\
\hline MAC $(\mathrm{cm})$ & $25.12+-4.06$ \\
\hline TSF $(\mathrm{cm})$ & $2.06+-0.640$ \\
\hline MAMC $(\mathrm{cm})$ & $23.81+-4.056$ \\
\hline S.albumin & $31.87+-5.788$ \\
\hline S.Cholesterol & $3.092+-0.784$ \\
\hline Dietary protein intake $(\mathrm{g} / \mathrm{kg} / \mathrm{day})$ & $0.68+-0.207$ \\
\hline $\begin{array}{l}\text { Dietary energy intake }(\mathrm{kCal} / \mathrm{kg} / \text { day }) \\
\mathrm{kcal} / \mathrm{kg} / \text { day }\end{array}$ & $27.99+-4.077$ \\
\hline
\end{tabular}

Table 2: Nutritional Assessment by different Tools $\mathrm{DMS}=$ Dialysis Malnutrition Score, $\mathrm{BMI}=$ Body Mass Index, $\mathrm{MAC}=\mathrm{Mid}$ Arm Circumference, $\mathrm{TSF}=$ Triceps Skin Fold Thickness, $\mathrm{MAMC}=\mathrm{Mid}$ Arm Muscle Circumference 


\begin{tabular}{|l|l|l|}
\hline Variable & R value & P Value \\
\hline Age in years & $.251^{*}$ & .043 \\
\hline Gender & .108 & .391 \\
\hline Ethnicity & -.028 & .824 \\
\hline Primary kidney disease & -.086 & .498 \\
\hline Family income & .158 & .210 \\
\hline Dialysis duration & .139 & .269 \\
\hline Number of dialysis per week & .140 & $.277-$ \\
\hline BMI $\left(\mathrm{kg} / \mathrm{m}^{2}\right)$ & .076 & .547 \\
\hline MAC $(\mathrm{cm})$ & $-.488^{* *}$ & .001 \\
\hline TSF $(\mathrm{cm})$ & $-.318^{* *}$ & .010 \\
\hline MAMC & $-.386^{* *}$ & 0.001 \\
\hline s.albumin & -.061 & .628 \\
\hline s. cholesterol & -.022 & .859 \\
\hline 24h dietary protein & $-.468^{* *}$ & 0.001 \\
\hline 24h dietary energy & -.132 & .294 \\
\hline
\end{tabular}

Table 3: Correlation of nutritional variables with DMS

*Denotes statistical significance, $\mathrm{BMI}=$ Body Mass Index, MAC $=\mathrm{Mid}$ Arm Circumference, TSF $=$ Triceps Skin Fold Thickness, MAMC $=$ Mid Arm Muscle Circumference

The study included 65 participants; with a mean age of 51.12+13.4.2 years. Table 1 illustrates the sociodemographic and haemodialysis parameters of the population. Majority were males $((63.1 \%))$. The most prevalent primary kidney diseases were hypertension (55.38\%), diabetes mellitus $(29.23 \%)$ and chronic kidney disease of unknown origin $(7.69 \%)$. The average family income was SLR 17,253.85+-16171.95. The mean duration on haemodialysis was $13.68+-11.62$ months. Most patients $(66.2 \%)$ were receiving haemodialysis only twice a week. Majority (58.46\%) were dialyzed using AVF.

As indicated in Table $2,78.5 \%$ of patients $(n=51)$ were categorised to have mild to moderate malnutrition based on dialysis malnutrition score. No patients were diagnosed with severe malnutrition category. Fourteen (21.54\%) patients were categorised as well nourished.

Table 2 shows the outcomes generated by different nutritional assessment tools. The average score of DMS in this study was 13.91+-4.193. Sixty-six percent of target population was found to have BMI of $<23 \mathrm{~kg} / \mathrm{m} 2$, while $83.3 \%$ showed serum albumin $<38 \mathrm{~g} / \mathrm{dl}$ according to criteria used to indicate protein energy wasting proposed by International Society of Renal Nutrition and Metabolism (ISRNM) expert panel [1].

The mean daily protein intake of study population was well below the recommended intake of $1.1 \mathrm{~g} / \mathrm{kg}$ body weight/day as proposed by renal association. A majority of $81.5 \%$ ate less than the recommended protein intake [1].

Table 3 shows the associations between the dialysis patients' quantitative dialysis malnutrition scores and nutritionally relevant parameters. The DMS correlated significantly with MAC $(\mathrm{r}=-$ $\left..488^{* *}, \mathrm{p}=.001\right)$, TSF $\left(\mathrm{r}=-.318^{* *}, \mathrm{p}=.010\right)$, MAMC $\left(\mathrm{r}=-.386^{* *}\right.$, $\mathrm{p}=0.001)$, daily protein intake $\left(\mathrm{r}=--.468^{* *}, \mathrm{p}=0.001\right)$ and age $\left(\mathrm{r}=.251^{*}, \mathrm{p}=0.043\right)$. All associations seem to be weak association as $r$ values were between 0.2 to 0.5 .

\section{Discussion}

\section{Method}

Evaluation of nutritional status in a haemodialysis patient is a challenge $[1,2]$. There are numerous tools available including anthropometric and biochemical measurements, yet their sensitivity in recognising early malnutrition, practicability and applicability to haemodialysis patients have not been convincing [10].

Modified Subjective Global Assessment- Dialysis Malnutrition Score has come as a reliable, valid method with a good correlation to other nutritional markers in patients with chronic kidney disease. Further, it is quantitative and provides prognostic evidence to predict poor outcome ${ }^{1}$. It is inexpensive, non-invasive, can be performed rapidly and requires only brief training Therefore; this tool was used as the main method of diagnosing malnutrition among haemodialysis patients in our study.

\section{Prevalence of Malnutrition}

The study depicted a high prevalence of mild to moderate malnutrition (78.5\%) among the study population based on DMS. A significant variation in prevalence of malnutrition was seen among countries. Some South Asian studies based on DMS showed malnutrition prevalence over $90 \%$ in haemodialysis patients [2,3]. In contrast, a much lower prevalence (approximating $30 \%$ ) was reported by several European studies based on Subjective Global Assessment [4, 5, 7].

Numerous factors play a role resulting in discrepancies in prevalence of malnutrition in different studies. These factors include utility of different evaluation methods, different health care systems, sample heterogeneity, diversity of dietary patterns, and variations in socioeconomic status between the countries ${ }^{2}$. Further, the dialysis mode, dose and frequency may affect the development of malnutrition ${ }^{3}$. In our study population, low frequency of haemodialysis $(\mathrm{n}=55\{84.6 \%\}$ received maximum two HD per week), low family income, low protein and energy diet may have contributed to the high prevalence. Further, Raguso, et al. showed that experience of the interviewer who administers SGA may influence the malnutrition classification [4].

\section{Associations}

Out study, depicted a strong correlation between ages, mid arm muscle circumference, daily protein intake with malnutrition. A significant association was not seen with other variables (gender, ethnicity, primary kidney disease, and family income, and dialysis duration, number of dialysis per week, BMI, S. albumin, S. cholesterol or $24 \mathrm{~h}$ dietary energy intake).

Age

The prevalence of malnutrition depicted a significant positive correlation with age. Though advancing age was not a predictor of malnutrition in most studies, Kalantar-Zadeh, et al, reported a similar association $[10,20]$. 
Advancing age is frequently associated with high occurrence of malnutrition due to multiple difficulties such as reduced appetite, poor dentition, and presence of comorbidities, reduced mobility and poor cognition.

\section{MAC, TSF and MAMC}

The study further indicated a very strong negative correlation between malnutrition and anthropometric measurements such as MAC, TSF and MAMC. Mid-arm muscle circumference (MAMC) is a bedside anthropometric measurement derived from MAC and TSF that estimates somatic protein reserve, an early indicator of nutritional depletion. Many studies show this consistent negative association between MAC, TSF, MAMC and malnutrition grading $[5,10,14,18,19]$.

Daily protein intake was also found to be strongly negatively associated with malnutrition score in this study. Further, literature suggests low dietary protein intake may be associated with increased risk of death among hemodialysis patients and it to be an independent risk factor for outcome [5-7].

Further, dietary protein intake (mean+-SD $=0.68+-0.207 \mathrm{~g} / \mathrm{kg}$ $\mathrm{BW} /$ day) was well below the recommend protein intake of 1.1-1.4 $\mathrm{g} / \mathrm{kg} \mathrm{BW} /$ day for patients on HD [14, 15]. In fact, $81.5 \%$ of population were taking proteins less than $1.1 \mathrm{~g} / \mathrm{kg} /$ day. Patients were also relying on a low energy diet (mean+-SD=27.99+-4.077), below the recommended $30-40 \mathrm{kCal} / \mathrm{kgIBW} /$ day although it didn't reveal a significant association with DMS. Similar findings were reported in some studies looking in to dietary intake in haemodialysis $[14,20]$. Continuing on recommended low protein diet for $\mathrm{CKD}$ in to haemodialysis, non-availability of renal dietitians, low socioeconomic status might have potentially resulted in these findings.

Therefore, incorporation of a nutritional assessment methodology and dietary intervention has become mandatory in current HD practice in the country.

\section{Serum albumin}

Our study didn't reveal a significant correlation between S. albumin and malnutrition score. This finding was consistently evident in many other studies, [15-16]. S albumin may be confounded by non-nutritional factors such as chronic inflammation, coexistent liver disease, fluid overload and iron deficiency anaemia [14].

Further, Qureshi et al showed that serum albumin levels may be low even in apparently well-nourished haemodialysis patients ${ }^{4}$. This study also showed $85.71 \%(n=12 / 14)$ of well-nourished patients showed low serum albumin levels lesser than $38 \mathrm{~g} / \mathrm{dl}$. Therefore, common utility of S. albumin as an isolated nutritional marker in a HD patient is questionable.

\section{BMI}

Moreover, no significant association between the malnutrition and the BMI was illustrated. This association is an inconsistent finding as several studies showed a significant correlation, while some didn't $[10,14,15]$. This discrepancy may be due to sub-adequate dialysis leading to fluid retention influencing weight measurement and erroneous BMI calculation. Therefore, nutritional assessment should not depend on the BMI alone. Further, according to KDOQI guidelines, the BMI threshold that indicates PEW in haemodialysis population is uncertain and varies among different ethnic groups [15].

It was a single centre observational study. The data were lacking in variables such as educational level, smoking, and co morbidity score to correlate with malnutrition. Inco-operation of $\mathrm{C}$ - reactive protein to assess the inflammation, dialysis dose to evaluate dialysis adequacy could have been important to correlate with malnutrition.

\section{Conclusion}

Prevalence of malnutrition is high in this Sri Lankan haemodialysis population. A Strong correlation was seen between Malnutrition score and advancing age, MAC, TSF, MAMC and daily protein intake. Regular Nutritional assessment and appropriate dietary and clinical management should be an integral part of maintenance haemodialysis provision [21-38].

\section{References}

1. Neuen BL, Chadban SJ, Demaio AR, Johnson DW, Perkovic $\mathrm{V}$, et al. (2017) Chronic kidney disease and the global NCDs agenda. BMJ Glob Health 2: e000380.

2. Liyanage T, Ninomiya $T$, Jha V, Bruce Neal, Halle Marie Patrice, et al. (2015) World wide access to treatment for end-stage kidney disease: a systematic review. Lancet 385: 1975-1982.

3. Liew A (2018) Perspectives in renal replacement therapy: Haemodialysis. Nephrology (Carlton) 4: 95-99.

4. Nunes FT, Campos G, Paula SMX, Merhi VAL, Portero Mclellan KC, et al. (2008) Dialysis adequacy and nutritional status of hemodialysis patients. Hemodial Int 12: 45-51.

5. Shah SN, Abramowitz M, Hostetter TH, Melamed ML (2009) Serum bicarbonate levels and the progression of kidney disease: a cohort study. Am J Kidney Dis 54:270-277.

6. Cardozo MT, Vieira IO, Campanella LCA (2006) Alterações nutricionais em pacientes renais crônicos em programa de hemodiálise. Rev Bras Nutr Clín 21: 284-289.

7. Segall L, Mardare NG, Ungureanu S, Busuioc M, Nistor I, et al. (2009) Nutritional status evaluation and survival in haemodialysis patients in one centre from Romania. Nephrol Dial Transplant 3: 1-5.

8. Enia G, Sicus C, Alati G, Zoccali C (1993) Subjective Global Assessment of nutrition in dialysis subjects. Nephrol Dial Transplant 8: 1094-1098.

9. Kalantar Zadeh K, Kleiner M, Dunne E, Ahern K, Nelson M, et al. (1998) Total iron-binding capacity-estimated transferrin correlates with the nutritional subjective global Assessment in hemodialysis subjects. Am J Kidney Dis 31:263-72. 
10. Kalantar Zadeh K, Kleiner M, Dunne E, Lee GH, Luft, FC, et al. (1999) A modified quantitative subjective global assessment of nutrition for dialysis subjects. Nephrol Dial Transplant 14: 1732-1738.

11. Asgarani F, Mahdavi Mazdeh M, Lessan Pezeshki M, Makhdoomi Kh A, Nafar M, at al. (2004) Correlation between modified subjective global assessment with anthropometric measurements and laboratory parameters. Acta Medica Irnica 42:331-337.

12. Reza Afshar, Suzan Sanavi , Akram Izadi Khah (2007) Assessment of Nutritional Status in Patients Undergoing Maintenance Hemodialysis: A Single-Center Study from Iran, Saudi journal of kidney diseases and transplantation 18: 397-404.

13. Fouque D, Kalantar Zadeh K, Kopple JD, Cano N, Chauveau $\mathrm{P}$, et al. (2008) A proposed nomenclature and diagnostic criteria for protein-energy wasting in acute and chronic kidney disease. Kidney Int 73: 391-398.

14. Wright M, Southcott E, MacLaughlin H, Stuart Wineberg (2019) Clinical practice guideline on undernutrition in chronic kidney disease. BMC Nephrol 20: 370.

15. Locatelli F, Fouque D, Heimburger O, Drueke TB (2002) Cannata-Andía JB, Horl $\mathrm{WH}$, et al. Nutritional status in dialysis patients: a European consensus. Nephrol Dial Transplant 17: 563-572.

16. Jones CH, Wolfenden RC, Wells LM (2004) Is subjective global assessment a reliable measure of nutritional status in hemodialysis? J Renal Nutr4: 26-30.

17. Campbell Katrina, Ash Susan, Bauer Judith, Davies PSW (2007) Critical review of nutrition assessment tools to measure malnutrition in chronic kidney disease. Nutrition \& Dietetics 64: $23-30$.

18. Vasantha Janardhan, P Soundararajan, N Vanitha Rani, G Kannan, P Thennarasu, Rosney Ann Chacko, C Uma Maheswara Reddy, Prediction of Malnutrition Using Modified Subjective Global Assessment-dialysis Malnutrition Score in Patients on Hemodialysis Indian journal of pharmaceutical sciences, 2011 Jan-Feb; 73(1): 38-45.

19. DN Manandhar, PK Chhetri, LR Pahari, R Tiwari, SK Chowdhary, et al. (2008) Nutritional assessment of patients under hemodialysis in Nepal Medical College Teaching Hospital Nepal Med Coll J 10: 164-169.

20. Oliveira GT, Andrade EI, Acurcio Fde A, Cherchiglia ML, Correia MI, et al. (1992) Nutritional assessment of patients undergoing hemodialysis at dialysis centers in Belo Horizonte, MG, Brazil. Rev Assoc Med Bras 58: 240-247.

21. Mutsert M, Grootendorst DC, Boeschoten EW, Brandts H, Manen JG, Krediet.

22. RT, et al. (2009) Subjective global assessment of nutritional status is strongly associated with mortality in chronic dialysis patients. Am J Clin Nutr 89: 787-793.
23. Mohammed FA, Farhood HF, AtheemWtwt MA (2014) Prediction of Malnutrition Using Modified Subjective Global Assessment-Dialysis Malnutrition Score in Patients on Chronic Hemodialysis. J Community Med Health Educ 4: 291.

24. Schulman G (2004) The dose of hemodialysis patients: impact on nutrition. Semin Dial 17:479-488.

25. Raguso CA, Maisonneuve N, Pichard C (2004) Subjective global assessment (SGA): evaluation and follow up of nutritional state. Rev Med Suisse Romande 124: 607-610.

26. Jahromi SR, Hosseini S, Razeghi E, Meysamie Ap, Sadrzadeh $\mathrm{H}$, et al. (2010) Malnutrition predicting factors in hemodialysis patients. Saudi J Kidney Dis Transpl 21: 846-851.

27. Kaysen GA, Chertow GM, Adhikarla R, Young B, Ronco C, et al. (2001) Inflammation and dietary protein intake exert competing effects on serum albumin and creatinine in hemodialysis patients. Kidney Int 60: 333-340.

28. Kalantar Zadeh K, Supasyndh O, Lehn RS, McAllister CJ, Kopple JD, et al. (2003) Normalized protein nitrogen appearance is correlated with hospitalization and mortality in hemodialysis patients with Kt/V greater than 1.20. J Ren Nutr 13: 15-25.

29. Zimmermann J, Herrlinger S, Pruy A, Metzger T, Wanner C (1999) Inflammation enhances cardiovascular risk and mortality in hemodialysis patients. Kidney Int. 55: 648-658.

30. Valenzuela RG, Giffoni AG, Cuppari L, Canziani ME (2003) Nutritional status in patients with chronic renal failure undergoing hemoddialysis in Amazonas. Rev Med Bras 49: 72-78.

31. Gama Axelsson T, Heimbürger $\mathrm{O}$, Stenvinkel P, Bárány $\mathrm{P}$, Lindholm B, et al. (2012) Serum albumin as predictor of nutritional status in patients with ESRD [published correction appears in Clin J Am Soc Nephrol. 2012 Nov;7(11):1915]. Clin J Am Soc Nephrol 7: 1446-1453.

32. Heimbürger O, Qureshi AR, Blaner WS, Berglund L, Stenvinkel P (2000) Hand-grip muscle strength, lean body mass, and plasma proteins as markers of nutritional status in patients with chronic renal failure close to start of dialysis therapy. Am J Kidney Dis 36: 1213-1225.

33. Bossola M, La Torre G, Giungi S, Tazza L, Vulpio C, Luciani G: Serum albumin, body weight and inflammatory parameters in chronic hemodialysis patients: A three-year longitudinal study. Am J Nephrol 28: 405-412, 2008.

34. Smedley F, Bowling T, James M, Stokes E, Goodger C, O'Connor O, et al. (2004) Randomized clinical trial of the effects of preoperative and postoperative oral nutritional supplements on clinical course and cost of care. Br J Surg 91: 983-990.

35. Qureshi AR, Alvestrand A, Danielsson A, Divino-Filho JC, Gutierrez A, et al. (1998) Factors predicting malnutrition in hemodialysis patients: a cross-sectional study. Kidney Int 53: 773-782. 
36. Harvinder GS, Swee WC, Karupaiah T, Sahathevan S, Chinna $\mathrm{K}$, et al. (2016) Dialysis malnutrition and malnutrition inflammation scores: Screening tools for prediction of dialysis-related protein-energy wasting in Malaysia. Asia Pac J Clin Nutr 25: 26-33.

37. DemiraÄ̈̈ A, Kalayci M, Kantarci G, GÃ |kÃ §e O (2009) Modified quantitative subjective global assessment of nutrition in patients on the renal transplant waiting list. Transplant Proc 41: 108-111.
38. Combe C, Keith P, Cullough, Yasushi Asano, Nancy Ginsberg, et al. (2004) Kidney Disease Outcomes Quality Initiative (K/ DOQI) and the Dialysis Outcomes and Practice Patterns Study (DOPPS): Nutrition Guidelines, Indicators, and Practices. AJKD 44: 39-46.
Copyright: (02020 Ratnapala DUS, et al. This is an open-access article distributed under the terms of the Creative Commons Attribution License, which permits unrestricted use, distribution, and reproduction in any medium, provided the original author and source are credited. 